\title{
Are men universally more dismissing than women? Gender differences in romantic attachment across 62 cultural regions
}

DAVID P. SCHMITT,${ }^{a}$ LIDIA ALCALAY,${ }^{b}$ MELISSA ALLENSWORTH, ${ }^{a}$ JÜRI ALLIK, ${ }^{c}$ LARA AULT, ${ }^{d}$ IVARS AUSTERS, ${ }^{e}$ KEVIN L. BENNETT ${ }^{f}$ GABRIEL BIANCHI, ${ }^{g}$ FREDRICK BOHOLST, ${ }^{h}$ MARY ANN BORG CUNEN,${ }^{i}$ JOHAN BRAECKMAN,${ }^{j}$ EDWIN G. BRAINERD JR., ${ }^{k}$ LEO GERARD A. CARAL,${ }^{l}$ GABRIELLE CARON,${ }^{m}$ MARIA MARTINA CASULLO,${ }^{n}$ MICHAEL CUNNINGHAM ${ }^{d}$ IKUO DAIBO,${ }^{o}$ CHARLOTTE DE BACKER ${ }^{j}$ EROS DE SOUZA ${ }^{p}$ ROLANDO DIAZ-LOVING,${ }^{q}$ GLÁUCIA DINIZ, ${ }^{r}$ KEVIN DURKIN,${ }^{s}$ MARCELA ECHEGARAY ${ }^{t}$ EKIN EREMSOY, ${ }^{u}$ HARALD A. EULER, ${ }^{v}$ RUTH FALZON,${ }^{i}$ MARYANNE L. FISHER,${ }^{w}$ DOLORES FOLEY,${ }^{x}$ ROBERT FOWLER,${ }^{a}$ DOUGLAS P. FRY,${ }^{y}$ SIRPA FRY,${ }^{y}$ M. ARIF GHAYUR, ${ }^{z}$ VIJAI N. GIRI ${ }^{a}{ }^{a}$ DEBRA L. GOLDEN, ${ }^{b b}$ KARL GRAMMER, ${ }^{c c}$ LIRIA GRIMALDI, ${ }^{d d}$ JAMIN HALBERSTADT ${ }^{e e}$ SHAMSUL HAQUE ${ }^{f f}$ DORA HERRERA,${ }^{t}$ JANINE HERTEL,${ }^{g g}$ AMANDA HITCHELL,${ }^{a}$ HEATHER HOFFMANN,${ }^{h h}$ DANICA HOOPER,${ }^{x}$ ZUZANA HRADILEKOVA,${ }^{i i}$ JASNA HUDEK-KENE-EVI ${ }^{i j}$ ALLEN HUFFCUTT,${ }^{a}$ JAS JAAFAR, ${ }^{k}{ }^{k}$ MARGARITA JANKAUSKAITE,${ }^{l}$ HEIDI KABANGU-STAHEL, ${ }^{m m}$ IGOR KARDUM, ${ }^{j j}$ BRIGITTE KHOURY, ${ }^{n n}$ HAYRRAN KWON,${ }^{o o}$ KAIA LAIDRA, ${ }^{c}$ ANTON-RUPERT LAIREITER,${ }^{p p}$ DUSTIN LAKERVELD,${ }^{q q}$ ADA LAMPERT,${ }^{r r}$ MARYANNE LAURI,${ }^{i}$ MARGEURITE LAVALLÉE, ${ }^{m}$ SUK-JAE LEE, ${ }^{s s}$ LUK CHUNG LEUNG, ${ }^{t t}$ KENNETH D. LOCKE, ${ }^{u u}$ VANCE LOCKE,${ }^{s}$ IVAN LUKSIK,,${ }^{p v}$ ISHMAEL MAGAISA, ${ }^{w w}$ DALIA MARCINKEVICIENE, ${ }^{x x}$ ANDRÉ MATA,${ }^{y y}$ RUI MATA,${ }^{y y}$ BARRY MCCARTHY ${ }^{z z}$ MICHAEL E. MILLS, ${ }^{a a}{ }^{a}$ NHLANHLA J. MKHIZE,${ }^{b b b}$ JOÃO MOREIRA,${ }^{y y}$ SÉRGIO MOREIRA,${ }^{y y}$ MIGUEL MOYA,${ }^{c c c}$ M. MUNYAE, ${ }^{d d d}$ PATRICIA NOLLER, ${ }^{x}$ HMOUD OLIMAT, ${ }^{e e e}$ ADRIAN OPRE,${ }^{f f f}$ ALEXIA PANAYIOTOU,${ }^{g g g}$ NEBOJSA PETROVIC, ${ }^{h h h}$ KAROLIEN POELS,${ }^{j}$ MIROSLAV POPPER, ${ }^{v v}$ MARIA POULIMENOU, ${ }^{i i}$ VOLODYMYR P'YATOKHA,${ }^{j j j}$ MICHEL RAYMOND,${ }^{k k k}$ ULF-DIETRICH REIPS, ${ }^{l l l}$ SUSAN E. RENEAU, ${ }^{m m m}$ SOFIA RIVERA-ARAGON,${ }^{q}$ WADE C. ROWATT,${ }^{n n}{ }^{n}$ WILLIBALD RUCH,${ }^{o o}$ VELKO S. RUS, ${ }^{p p p}$ MARILYN P. SAFIR, ${ }^{q q q}$ SONIA SALAS,${ }^{r r r}$ FABIO SAMBATARO,${ }^{d d}$ KENNETH N. SANDNABBA,${ }^{y}$ RACHEL SCHLEETER, ${ }^{a}$ MARION K. SCHULMEYER, ${ }^{s s s}$ ASTRID SCHÜTZ, ${ }^{g g}$ TULLIO SCRIMALI, ${ }^{d d}$ TODD K. SHACKELFORD ${ }^{t t t}$ MITHILA B. SHARAN,${ }^{a a}$ PHILLIP R. SHAVER, ${ }^{u u u}$ FRANCIS SICHONA, ${ }^{v v v}$ FRANCO SIMONETTI, ${ }^{b}$ TILAHUN SINESHAW, ${ }^{{ }^{w w w}}{ }^{\mathrm{R}}$. SOOKDEW, ${ }^{b b b}$ TOM SPEELMAN,${ }^{j}$ SPYROS SPYROU,${ }^{x x x} \mathrm{H}$. CANAN SÜMER,${ }^{y y y}$ NEBI SÜMER,${ }^{y y y}$ MARIANNA SUPEKOVA, ${ }^{p v}$ TOMASZ SZLENDAK, ${ }^{z z z}$ ROBIN TAYLOR, ${ }^{a a a a}$ BERT TIMMERMANS, ${ }^{b b b b}$ WILLIAM TOOKE ${ }^{c c c c}$ IOANNIS TSAOUSIS,${ }^{d d d d}$ F.S.K. TUNGARAZA, ${ }^{\text {eeee ASHLEY }}$ TURNER, ${ }^{a}$ GRIET VANDERMASSEN,${ }^{j}$ TIM VANHOOMISSEN,${ }^{f f f f}$ FRANK VAN OVERWALLE ${ }^{f f f f}$ INE VANWESENBEECK, ${ }^{g g g g}$ PAUL L. VASEY, ${ }^{h h h h}$ JOÃO VERISSIMO,${ }^{y y}$ MARTIN VORACEK, ${ }^{i i i i}$ WENDY W. N. WAN, ${ }^{i j j j}$ 
TA-WEI WANG, ${ }^{k k k}$ PETER WEISS, ${ }^{l l l}$ ANDIK WIJAYA, ${ }^{m m m m}$ LIESBETH WOERTMAN, ${ }^{n n n}$ GAHYUN YOUN, ${ }^{o o o}$ AGATA ZUPANĖIÈ, ${ }^{p p p}$

${ }^{a}$ Bradley University, USA $;{ }^{b}$ Pontificia Universidad Católica de Chile, Chile; ${ }^{c}$ University of Tartu, Estonia; ${ }^{d}$ University of Louisville, USA; ${ }^{e}$ University of Latvia, Latvia, ${ }^{f}$ University of New Mexico, USA; ${ }^{g}$ Slovak Academy of Sciences, Slovak Republic; ${ }^{h}$ University of San Carlos, Philippines; ${ }^{i}$ University of Malta, Malta; ${ }^{j}$ Ghent University, Belgium; ${ }^{k}$ Clemson University, USA; ${ }^{l}$ University of San Carlos, Philippines; ${ }^{m}$ Université of Laval, Canada; ${ }^{n}$ University of Buenos Aires, Argentina; ${ }^{o}$ Osaka University, Japan; ${ }^{p}$ Illinois State University, USA; ${ }^{q}$ National Autonomous University of Mexico, Mexico; ${ }^{r}$ University of Brasilia, Brazil; ${ }^{s}$ The University of Western Australia, Australia; ${ }^{t}$ University of Lima, Peru; ${ }^{u}$ Bogazici Universitesi, Turkey; ${ }^{v}$ University of Kassel, Germany; ${ }^{w}$ York University, Canada; ${ }^{x}$ University of Queensland, Australia; ${ }^{y}$ A bo Akademi University, Finland; ${ }^{z}$ Al-Akhawayn University, Morocco; ${ }^{a}$ Indian Institute of Technology, Kharagpur, India; ${ }^{b b}$ University of Hawaii-Manoa, USA; ${ }^{c c}$ Ludwig-Boltzmann-Institute for Urban Ethology, Austria;

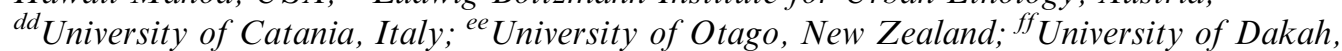

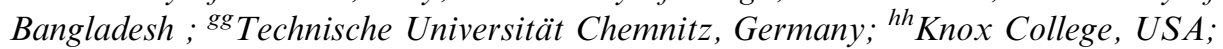

${ }^{i i}$ Comenius University, Slovak Republic; ${ }^{i j}$ University of Rijeka, Croatia; ${ }^{k k}$ University of Malaya, Malaysia; "Vilnius University, Lithuania; ${ }^{m m}$ Centre d'Enseignement les Gazelles, Democratic Republic of the Congo; ${ }^{n n}$ American University of Beirut, Lebanon; ${ }^{o o}$ Kwangju Health College, Republic of Korea; ${ }^{p p}$ Institute of Psychology, University of Salzburg, Austria; ${ }^{q q}$ University of Utrecht, Netherlands; ${ }^{r r}$ The Ruppin Institute, Israel; ${ }^{\text {ss National }}$

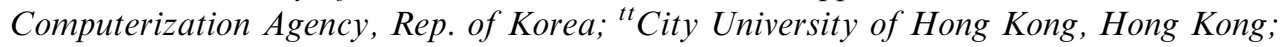
${ }^{u u}$ University of Idaho, USA ${ }^{v v}$ Slovak Academy of Sciences, Slovak Republic; ${ }^{\text {ww }}$ University of Zimbabwe, Zimbabwe; ${ }^{x x}$ Vilnius Univeristy, Lithuania; ${ }^{y y}$ University of Lisbon, Portugal; ${ }^{z z}$ University of Central Lancashire, England; ${ }^{a a a}$ Loyola Marymount University, USA; ${ }^{b b b}$ University of Natal, South Africa; ${ }^{c c c}$ University of Granada, Spain; ${ }^{d d d}$ University of Botswana, Botswana; ${ }^{e e e}$ University of Jordan, Jordan; ${ }^{f f f}$ Babes Bolyai University, Romania; ${ }^{g g g}$ University of Cyprus, Cyprus; ${ }^{\text {hhh }}$ University of Belgrade, Serbia; ${ }^{i i i}$ KPMG Kyriacou Counsultants $S A$, Greece; ${ }^{j j j}$ Volyn Regional Hospital, Ukraine; ${ }^{k k k}$ Université de Montpellier II, France; "ll Universität Zürich, Switzerland; ${ }^{m m m}$ University of Alabama, USA; ${ }^{n n n}$ Baylor University, USA; ${ }^{o o o}$ Queens University Belfast, Northern Ireland; ${ }^{\text {ppp }}$ Univeristy of Ljubljana, Slovenia; ${ }^{q q q}$ University of Haifa, Israel; ${ }^{r r r}$ Universidad de La Serena, Chile; ${ }^{s s s}$ Universidad Privada de Santa Cruz de la Sierra, Bolivia; ${ }^{\text {ttt }}$ Florida Atlantic University, USA; ${ }^{\text {иu }}$ University of California-Davis, USA; ${ }^{v v v}$ University of Dar es Salaam, Tanzania; ${ }^{w w w}$ Ramapo College of New Jersey, USA; ${ }^{x x x}$ Cyprus College, Cyprus; ${ }^{y y y}$ Middle East Technical University, Turkey; ${ }^{z z z}$ Nicholas Copernicus University, Poland; ${ }^{a a a}{ }^{2}$ University of the South Pacific, Fiji; ${ }^{b b b b}$ Vrije Universiteit, Belgium; ${ }^{c c c c}$ SUNY-Plattsburgh, USA; ${ }^{d d d d}$ University of the Aegean, Greece; ${ }^{\text {eeee }}$ University of Dar es Salaam, Tanzania; ${ }^{f f f f}$ Vrije

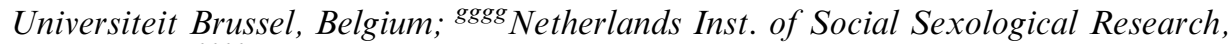

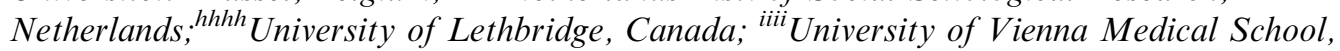

The authors thank Susan Sprecher (USA), Del Paulhus (Canada), Glenn D. Wilson (England), Qazi Rahman (England), Alois Angleitner (Germany), Angelika Hofhansl (Austria), Tamio Imagawa (Japan), Minoru Wada (Japan), Junichi Taniguchi (Japan), and Yuji Kanemasa (Japan) for helping with data collection and contributing significantly to the samples used in this study.

Correspondence should be sent to David P. Schmitt, Department of Psychology, Bradley University, Peoria, IL 61625; e-mail: dps@bradley.edu.

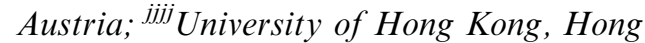
Kong; ${ }^{k k k k}$ National Changhua University of Education, Taiwan; ${ }^{l l l l}$ Charles University,

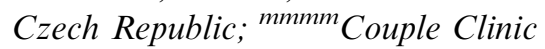
Indonesia, Surabaya, Indonesia; ${ }^{n n n n}$ Utrecht

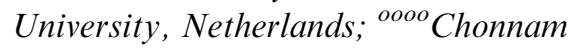
National University, Republic of Korea 


\begin{abstract}
Gender differences in the dismissing form of adult romantic attachment were investigated as part of the International Sexuality Description Project - a survey study of 17,804 people from 62 cultural regions. Contrary to research findings previously reported in Western cultures, we found that men were not significantly more dismissing than women across all cultural regions. Gender differences in dismissing romantic attachment were evident in most cultures, but were typically only small to moderate in magnitude. Looking across cultures, the degree of gender differentiation in dismissing romantic attachment was predictably associated with sociocultural indicators. Generally, these associations supported evolutionary theories of romantic attachment, with smaller gender differences evident in cultures with high-stress and high-fertility reproductive environments. Social role theories of human sexuality received less support in that more progressive sex-role ideologies and national gender equity indexes were not cross-culturally linked as expected to smaller gender differences in dismissing romantic attachment.
\end{abstract}

In this article, we report findings from the International Sexuality Description Project (ISDP), a research collaboration involving more than 100 social, behavioral, and biological scientists from 62 cultural regions representing 56 separate nations. The focus of this article is on adult romantic attachment, specifically gender differences in the "dismissing" form of adult romantic attachment. Dismissing romantic attachment orientations are indicated by an avoidance of close personal relationships and the tendency to prevent romantic disappointment by maintaining a sense of relational independence and emotional distance (Bartholomew, 1990; Bartholomew \& Horowitz, 1991). It is a common stereotype in Western culture that men are more emotionally distant and dismissing than women (Bem, 1993), and empirical studies have tended to substantiate this socioemotional portrayal of men, especially in the context of romantic relationships (e.g., Scharfe \& Bartholomew, 1994). In the current study, we critically evaluated whether men are universally more dismissing than women by testing for gender differences in dismissing romantic attachment across a wide spectrum of cultural regions. We also explored possible sociocultural moderators of gender differences in dismissing attachment, and addressed how well social role and evolutionary psychological theories of human sexuality explained genderdifferentiated patterns of dismissing romantic attachment across cultures.

Attachment theory and romantic relationships

According to Bowlby's (1969/1982) ethological theory of attachment, humans possess a behavioral-motivational system that emerges in infancy and is designed to protect children as they pass through several phases of development. It is generally assumed that successful navigation through the universal stages of attachment provides children with a secure emotional base from which they can competently lead the rest of their relational lives (Bowlby, 1988). Beginning with the work of Ainsworth and her colleagues (Ainsworth, Blehar, Waters, \& Wall, 1978), developmental psychologists have consistently found that supportive caregiving environments provide children with the healthiest and most secure attachment experiences, whereas insensitive and inconsistent caregiving lead to insecure attachment styles and unhealthy interpersonal functioning (Dozier, Stovall, \& Albus, 1999; Greenberg, 1999). Evidence also suggests that these early attachment styles affect our ability to relate to others in close personal relationships well into adulthood (Simpson \& Rholes, 1998; Waters, Merrick, Treboux, Crowell, \& Albertstein, 2000). For example, attachment stylesboth secure and insecure - seem to have an enduring influence on parent-child relations (George \& Solomon, 1999; Rholes, Simpson, \& Blakely, 1995), peer relationships and friendships (Allen \& Land, 1999; Feeney, Noller, \& Patty, 1993), teacher-student dynamics (Sroufe, 1983), therapeutic interactions (Slade, 1999), and even the way people form close relationships with God (Kirkpatrick, 1999).

In the mid-1980s, researchers began to investigate how attachment styles and orientations might apply to people's 
cognitive-emotional attitudes toward romantic love and sexual relationships (Hazan \& Shaver, 1987). Over the past decade and a half, a growing body of evidence has shown that attachment orientations deeply influence the way people think and feel about their romantic relationships (Collins \& Read, 1994; Feeney \& Noller, 1996; Klohnen \& John, 1998). Variation in adult attachment orientation has been linked to patterns of romantic relationship conflict and stress (Rholes, Simpson, \& Stevens, 1998; Simpson, 1990) and romantic satisfaction and harmony (Brennan \& Shaver, 1995; Collins \& Read, 1990), as well as the temporal duration of romantic relationships (Kirkpatrick, 1998; Simpson, 1999). In general, people with secure attachment styles tend to experience less conflict, more satisfaction, greater stability, and longer duration in their romantic relationships (Belsky, 1999; Kirkpatrick \& Hazan, 1994). People with insecure attachment styles tend to experience more conflict, less satisfaction, lower stability, and shorter durations in their romantic relationships (Brennan \& Shaver, 1995; Hazan \& Zeifman, 1999).

\section{Gender differences in dismissing romantic attachment}

According to the early studies of adult romantic attachment (e.g., Hazan \& Shaver, 1987), no gender differences were thought to exist in romantic attachment styles. Men and women were equally likely to be secure or insecure, a finding in line with the lack of observed gender differences in childhood attachment (Ainsworth et al., 1978). However, subsequent research using more continuous measures of adult romantic attachment and employing the four-category model of attachment (Bartholomew \& Horowitz, 1991) found men to be significantly more dismissing in romantic attachment orientation than women (Brennan, Clark, \& Shaver, 1998; Scharfe \& Bartholomew, 1994). In a review by Kirkpatrick (1998), gender differences in dismissing attachment were documented across numerous unpublished studies as well. Generally, the dismissing form of insecure romantic attachment is associated with an avoidance of interpersonal closeness, a discomfort with emotional disclosure, and a desire for relational independence (Bartholomew, 1990).

The finding of gender differences in dismissing romantic attachment seems to fit with common beliefs about social and emotional differences between the sexes, with men usually seen as less emotional, less nurturing, and less willing to connect with others (Bem, 1974, 1993; Spence \& Helmreich, 1978). Men's greater dismissiveness is likewise consistent with self-report surveys of emotional distance and social restrictiveness. In a review of literature on gender and emotion, Brody and Hall (1993) concluded that men are much less likely than women to express emotions associated with affiliation and social bonding (see also Geary, 1998). Men are also less likely than women to seek emotional support when coping with stress (Tamres, Janicki, \& Helgeson, 2002; Taylor et al., 2000). In a large meta-analysis of gender differences in personality traits (Feingold, 1994), men were shown to be less nurturing, trusting, and gregarious than women - a trait profile closely aligned with the dismissing form of romantic attachment. Research on romantic couples has revealed that men report less comfort with emotional closeness in their relationships (Feeney, 1994), whereas women more often complain of men's lack of closeness (Buss, 1989a) and find more satisfying those men who show fewer indications of dismissing romantic attachment (Collins \& Read, 1990; Kirkpatrick \& Davis, 1994; Simpson, 1990). Even though within-sex variation in dismissing romantic attachment can be considerable (Bartholomew \& Horowitz, 1991), several sources of evidence-social stereotypes, self-perception differences, coping responses, and romantic partner-reported reactions - all seem to converge on the notion that men, on average, are significantly more dismissing in romantic attachment orientation than women.

Still, it may be premature to conclude that human males, as a group, are universally more dismissing in romantic 
attachment than human females. One reason for skepticism is that the preponderance of studies that have profiled men as the more dismissing gender have been conducted in Western cultures, limited primarily to North America, Western Europe, and Australasia (Brennan et al., 1998). Recently, a large cross-cultural study by Schmitt and more than 100 colleagues (Schmitt, Alcalay, Allensworth, Allik, Ault et al., in press) found that dismissing romantic attachment levels vary widely across non-Western cultures. Cultures from South America, Southern Europe, and East Asia displayed much lower levels of dismissing attachment than other parts of the world. Cultures from Africa, Oceania, and South/Southeast Asia tended to display heightened levels of dismissing romantic attachment (Schmitt et al., in press). This cross-cultural variability in romantic attachment seems to mirror the results from previous studies of parentchild attachment (Van IJzendoorn \& Sagi, 1999). Furthermore, Costa, Terracciano, and McCrae (2001) have found that gender differences in many personality traits, including those linked to dismissiveness such as disagreeableness and introversion, are "most marked among European and American cultures and most attenuated among African and Asian cultures" (p. 327). With substantive variation in dismissing romantic attachment across non-Western cultures, and with inconsistent gender differences in traits linked to dismissing attachment, it remains unclear whether gender differences in dismissing romantic attachment fully generalize to all cultural regions of the world. On the other hand, there are compelling theoretical reasons to expect pancultural gender differences in dismissing romantic attachment.

\section{Evolutionary psychology and gender differences across cultures}

Many evolutionary psychological theories of romantic attachment would predict that gender differences in dismissing romantic attachment should generalize across most cultures. For example, Kirkpatrick (1998) has suggested that the psychology of dismissing romantic attachment is conceptually similar to the psychology of shortterm mating, perhaps even synonymous with it (see also Belsky, 1999; Simpson, 1999). Adults who report higher levels of dismissing romantic attachment tend to have more accepting attitudes toward casual sex, and engage in more promiscuous and indiscriminate sex, than people with more secure attachment styles (Bogaert \& Sadava, 2002; Brennan \& Shaver, 1995; Feeney, Noller, \& Patty, 1993; Schmitt, 2003a; Stephan \& Bachman, 1999). In a recent cross-cultural study involving more than 50 nations, Schmitt (2003b) documented that short-term mating tendencies are linked with higher levels of dismissing attachment, more so than with any other form of romantic attachment. When combined with the evolutionary premise that men are designed to follow short-term mating strategies and desire indiscriminate sex more than women are (Buss \& Schmitt, 1993; Schmitt, 2003c; Symons, 1979), this would imply that men may be designed in some ways to exhibit more dismissing romantic attachment orientations than women. Evolutionary psychologists have also argued that men's natural dismissiveness serves an evolved function once they are in in romantic relationships, a function in which withholding emotions protects men against women's probes into male commitment and fidelity (Buss, 1994). Based on these evolutionary perspectives, men may be more dismissing in romantic attachment than women across most cultures because of the evolved design features of men's mating psychology.

It is important to note, however, that evolutionary psychology perspectives do not expect that all cultures should have precisely the same level of gender difference in dismissing romantic attachment, nor that gender differences must be large in magnitude across all cultures if the differences are due, in part, to evolved sexual differentiation. This is sometimes how evolutionary theories are portrayed but it is a distorted picture of the evolutionary perspective on 
sexual differentiation (Mealey, 2000). If a psychological gender difference does not always appear in every culture, or is somewhat diminished across some cultures, this is not prima facie evidence that the gender difference is largely unrelated to evolved biology (Cronk, 1999; Lonner, 1980). Instead, there are sometimes adaptive reasons why, even though men and women are biologically designed with a propensity to differ in certain ways, they sometimes fail to display the exact same amount of difference across all cultures. For example, evolved gender differences may require certain developmental inputs that sometimes vary with local ecological conditions (Alexander, 1990; Low, 2000).

\section{Evolutionary psychology and gender differences in dismissing romantic attachment across cultures}

An ecological condition that may have a special impact on gender differences in dismissing romantic attachment is the amount of stress in local reproductive environments. Some cultures possess high-stress reproductive environments (Chisholm, 1999; Keller, 1990). Cultures with high levels of pathogens and disease, for example, are thought to present high-stress reproductive environments because raising offspring in diseaseprone environments is often associated with higher childhood mortality (see Gangestad \& Buss, 1993; Low, 1990). Indeed, mortality rate (or low life expectancy) itself is a strong indicator of environmental or ecological stress load. Reproductive environments with high fertility rates and scarce resources can also be considered stressful because human children, relative to other primate species, require heavy parental investment and raising multiple offspring makes it more difficult to invest the necessary amounts of care in each child (EiblEibesfeldt, 1989; Harvey \& Clutton-Brock, 1985; Trivers, 1972).

According to Belsky, Steinberg, and Draper (1991), when reproductive environments are particularly stressful women may be designed to shift away from their primary long-term mating strategy with its accompanying low levels of dismissing romantic attachment (Belsky, 1999; Kirkpatrick, 1998), and instead develop a more short-term mating strategy with higher levels of dismissing attachment (see also Chisholm, 1996). In women, this adaptive shift to a dismissing/short-term strategy may be based in part on several factors: on early reproduction that allows their family members to help raise offspring (Burton, 1990; Lancaster, 1989), on mating with multiple men in order to garner resources or protection from more than one putative father (Hrdy, 1981; Smuts, 1985), and on obtaining access via short-term mating to valuable men possessing "good genes," genes that are better able to withstand the pathogens and developmental stressors of harsh environments (Gangestad, 2001; Gangestad \& Simpson, 2000). Thus, women's dismissing romantic attachment levels may be culturally contingent, adaptively shifting in accord with the harsh physical environments (Belsky et al., 1991) and high fertility trends (Chisholm, 1996) of their local ecologies (see also Greiling \& Buss, 2000).

Men may also be driven toward shortterm mating and dismissing attachment in high-stress reproductive environments, but the effect appears to be more pronounced in women (Draper \& Harpending, 1982; Ellis, McFadyen-Ketchum, Dodge, Pettit, \& Bates, 1999). Perhaps this is due to men having evolved to preferentially follow more of an unrestricted or short-term reproductive strategy (Kenrick, Sadalla, Groth, \& Trost, 1990; Schmitt, 2002c; Simpson \& Gangestad, 1991), at least when doing so is unlikely to have strong negative consequences on survival (Schmitt \& Buss, 2001). Therefore, men's culturally contingent movement to short-term mating and dismissing romantic attachment in highstress reproductive environments may be less conspicuous or severe than women's shift.

This evolutionary perspective on romantic attachment leads to the following series of predictions concerning the magnitude of 
gender differences in dismissing romantic attachment across cultures.

Evolutionary Hypothesis 1:

Gender differences in the dismissing form of romantic attachment should exist across most cultures.

This hypothesis is based on the presumption that men are generally more oriented toward short-term mating via indiscriminate sex than women are (Buss \& Schmitt, 1993; Schmitt, Shackelford, Duntley, Tooke, \& Buss, 2001), and dismissing romantic attachment in adults is indicative of short-term mating tendencies (Kirkpatrick, 1998; Simpson, 1999).

\section{Evolutionary Hypothesis 2:}

Gender differences in dismissing romantic attachment should be smaller in cultures with high-stress environments.

This hypothesis is based, in part, on the notion that reproductively stressful environments trigger women's tendency toward short-term mating (Belsky et al., 1991; Ellis et al., 1999), including the adaptive desire for briefly mating with men who possess "good genes" (Gangestad, 2001; Gangestad \& Simpson, 2000). Because high levels of dismissing romantic attachment are indicative of short-term mating tendencies (Kirkpatrick, 1998; Simpson, 1999), and because men are typically more oriented toward short-term mating via indiscriminate sex than women are (Schmitt et al., 2001), women's levels of dismissing romantic attachment should become more similar to men's in cultures with high-stress environments.

Evolutionary Hypothesis 3:

Gender differences in dismissing romantic attachment should be smaller in cultures with higher fertility rates.

Higher fertility levels are associated with less emotional investment in children, a trend that is linked across cultures with the development of dismissing forms of attachment (Chisholm, 1996). High fertility levels are also associated with short-term mating tendencies (Keller, 1990). Because high levels of dismissing romantic attachment are indicative of short-term mating tendencies (Kirkpatrick, 1998; Simpson, 1999), and because men are typically more oriented toward short-term mating via indiscriminate sex than women are (Schmitt et al., 2001), women's levels of dismissing romantic attachment should become more similar to men's in cultures with higher fertility rates.

\section{Social role theory and variation in gender differences across cultures}

Social role theories typically suggest that men and women may sometimes differ in manifest behavior, but not because they have innate sex-differentiated psychologies. Instead, when men and women appear to differ it is because they inhabit different social or gender roles and have received dissimilar socialization experiences throughout development (Eagly, 1987; Wood \& Eagly, 2002). In this view, crosscultural gender differences in dismissing romantic attachment likely stem from men's pancultural socialization to be less comfortable with close emotional relationships than women, and conversely from women's universal socialization to be more nurturing and attendant to the emotions of others (Low, 1989; Munroe \& Munroe, 1997; Quinn, 1977). Moreover, once these men and women have been socialized into discrete gender roles, cognitive expectations concerning gender differences in emotional closeness would tend to pervade the activities of men and women throughout social life (Bem, 1993; Wood, Christensen, Hebl, \& Rothgerber, 1997). Of course, a proximate social role explanation such as this leaves open the question of why men and women would be socialized differently across all cultures to begin with.

Eagly and Wood (1999) presented a version of social role theory in which they provided an evolutionary rationale for why men and women are socialized differently across all cultures, and they did so while 
maintaining an emphasis on socialization as the primary causal agent of gender differences in sexual behavior. Eagly and Wood reasoned that physical differences between men and women, and the accompanying division of labor that those differences necessitated throughout human evolution, led to a long and consistent history of men and women filling different social roles or structures. Once in those social structures, men and women are assumed to make rational decisions that "maximize their outcomes within the constraints that societies establish for people of their sex" (Eagly \& Wood, 1999, p. 413). So, although biological differences between men and women initially create different social roles, it is the developmental experience of inhabiting different social roles and structures that directly causes most psychological gender differences. Importantly, the degree to which men and women are forced to inhabit bifurcated gender roles, and eventually develop some degree of psychological difference, is something that can presumably vary across cultures (Williams \& Best, 1990).

Using this social structure approach, Eagly and Wood (1999) went on to argue that many of the gender differences previously portrayed by evolutionists as biological adaptations, such as women's universal preference for mating with partners that have good earning capacity (Buss, 1989b), are instead the result of historical and environmental factors that contribute to gender-differentiated social roles and socialization across cultures. As evidence in favor of this position, Eagly and Wood noted that in cultures where women have more access to political and economic power, gender differences in desires for mating partners with resources are smaller (see also Kasser \& Sharma, 1999). Thus, women's pancultural desire for potential mates with resources can be seen as the reasoned consequence of inhabiting resource-depleted social structures, not a biological adaptation residing within women's evolved mating psychology (Wood \& Eagly, 2002).
Social role theory and gender differences in dismissing romantic attachment across cultures

From this social structure perspective, gender differences in dismissing romantic attachment and emotional closeness may also result from biologically generated social role differences, especially the different family roles that men and women naturally inhabit. Of crucial importance is the social structure of women more often being assigned the task of child rearing. "The assignment of the majority of child rearing to women encourages nurturant behaviors that facilitate care for children and other individuals. The importance of close relationships to women's nurturing role favors the acquisition of superior interpersonal skills and the ability to communicate nonverbally" (Eagly \& Wood, 1999, p. 413). In most cultures, young girls are usually channeled into nurturing social roles and are socialized to be sensitive to the emotions of others, including their young children (Munroe \& Munroe, 1997; Pasternak, Ember, \& Ember, 1997; Quinn, 1977). Women's gender roles and socialization experiences, it could be argued, are what cause lower levels of dismissing romantic attachment in women. Differences in the social structures that men and women inhabit as adults, and in the expectations of greater female nurturance in most cultures, may help to reinforce these universal gender differences in emotional sensitivity and dismissiveness (see also Hofstede, 1998).

An important implication of this social structural perspective is that in cultures where women are more severely restricted to childrearing (i.e., cultures with "traditional" sex-role ideologies; see Williams \& Best, 1990), gender differences in dismissing attachment should be larger because men and women have been forcibly channeled down separate social roles, with women experiencing more nurturing-based roles and social expectations. Within cultures that possess more "modern" or "progressive" sex-role ideologies, however, women are allowed to explore a wider array of 
social roles, including those that may involve less nurturing and the development of more dismissing attachment orientations. Indeed, both men and women enjoy less burdensome and gender-constraining social structures in cultures with modern sex-role ideologies. Consequently, gender differences in dismissing romantic attachment should be smaller, or perhaps even absent, in cultures where either gender can take on the role of family nurturer, "when men and women occupy the same specific social role, sex differences would tend to erode" (Eagly \& Wood, 1999, p. 413).

This social role perspective on romantic attachment leads to the following series of predictions concerning the magnitude of gender differences in dismissing romantic attachment across cultures.

\section{Social Role Hypothesis 1:}

Gender differences in the dismissing form of romantic attachment should exist across most cultures.

Gender differences should reliably emerge because physical differences between men and women have historically left women in the social role of childcare provider across most, if not all, human cultures (Eagly \& Wood, 1999; Quinn, 1977). Gender differences in dismissing romantic attachment, therefore, are an expected consequence of women having universally inhabited the social role of nurturer.

\section{Social Role Hypothesis 2:}

Gender differences in dismissing romantic attachment should be smaller in cultures with modern or progressive sex-roles ideologies.

This hypothesis is based on the idea that when women are neither expected nor forced to reside solely in the role of nurturer, men's and women's psychologies should become more similar (Eagly \& Wood, 1999). Thus, in cultures with more modern sex-role ideologies, men and women should be more similar in dismissing romantic attachment.
Social Role Hypothesis 3:

Gender differences in dismissing romantic attachment should be smaller in cultures where women have access to political and economic power.

Women's access to power across cultures is associated with smaller differences between men's and women's sexual psychology (Eagly \& Wood, 1999; Kasser \& Sharma, 1999; Wood \& Eagly, 2002). Thus, in cultures with more political-economic gender equality, men and women should be more similar in dismissing romantic attachment.

\section{Method}

\section{Participants}

The research reported in this paper is a result of the International Sexuality Description Project (ISDP). As shown in Table 1, the ISDP involved 10 geographically based world regions, each with a number of cultural regions: North America (which included 8 cultural regions), South America (5 regions), Western Europe (9 regions), Eastern Europe (11 regions), Southern Europe (6 regions), Middle East (4 regions), Africa (7 regions), Oceania (3 regions), South/Southeast Asia (5 regions), and East Asia (4 regions). Thus, participants represented 62 cultural regions in 56 countries of the world, located in 6 different continents and 13 islands. For some cultures (i.e., Australia, Austria, CanadaEnglish, Chile, England, Germany, Israel, Malta, South Korea, Turkey, and the USA Midwest, South, and West regions) more than one sample was collected. It is important to acknowledge that in a few cases placement of cultures into world regions is open to debate. For example, Turkey could have been placed into several possible regional categories, including Southeastern Europe, Mediterranean, or Southwestern Asian regions.

Most sample groups $(N=52)$ were comprised of college students; some $(N=8)$ included college students plus general 
Table 1. Men's and women's sample sizes and sex differences in dismissing romantic attachment across 62 cultural regions

\begin{tabular}{|c|c|c|c|c|c|c|c|c|}
\hline \multirow[b]{3}{*}{ Cultural regions } & \multicolumn{2}{|c|}{ Sample size } & \multicolumn{4}{|c|}{ Dismissing attachment } & \multicolumn{2}{|c|}{ Sex difference } \\
\hline & \multirow{2}{*}{$\frac{\text { Men }}{n}$} & \multirow{2}{*}{$\frac{\text { Women }}{n}$} & \multicolumn{2}{|c|}{ Men } & \multicolumn{2}{|c|}{ Women } & \multirow{2}{*}{$\frac{\text { Significance }}{t}$} & \multirow{2}{*}{$\frac{\text { Magnitude }}{d}$} \\
\hline & & & $M$ & $S D$ & $M$ & $S D$ & & \\
\hline \multicolumn{9}{|l|}{ North America } \\
\hline \multicolumn{9}{|l|}{ Canada } \\
\hline Canada-English & 313 & 553 & 4.22 & 1.60 & 3.66 & 1.59 & $5.01 * * *$ & 0.35 \\
\hline Canada-French & 60 & 113 & 3.59 & 1.59 & 3.62 & 1.91 & -0.11 & -0.02 \\
\hline \multicolumn{9}{|c|}{ United States of America (USA) } \\
\hline USA-Northeast & 72 & 156 & 4.18 & 1.61 & 3.78 & 1.78 & 1.65 & 0.23 \\
\hline USA-Midwest & 184 & 357 & 4.25 & 1.60 & 3.97 & 1.68 & 1.84 & 0.17 \\
\hline USA-South & 368 & 570 & 4.07 & 1.68 & 3.76 & 1.74 & $2.68 * *$ & 0.18 \\
\hline USA-West & 287 & 487 & 4.13 & 1.67 & 3.69 & 1.71 & $3.46 * * *$ & 0.26 \\
\hline USA-Hawaii & 88 & 224 & 4.60 & 1.45 & 3.80 & 1.72 & $3.88 * * *$ & 0.43 \\
\hline Mexico $^{\mathrm{a}}$ & 106 & 109 & 4.31 & 1.82 & 3.82 & 1.95 & 1.89 & 0.26 \\
\hline \multicolumn{9}{|l|}{ South America } \\
\hline Peru & 106 & 100 & 3.95 & 1.71 & 3.53 & 1.67 & 1.77 & 0.25 \\
\hline Bolivia & 92 & 89 & 4.50 & 1.67 & 4.17 & 1.82 & 0.73 & 0.19 \\
\hline Chile & 100 & 212 & 3.57 & 1.75 & 2.94 & 1.48 & $3.28 * * *$ & 0.39 \\
\hline Argentina & 110 & 136 & 2.76 & 1.79 & 2.21 & 1.60 & $2.54 * *$ & 0.32 \\
\hline Brazil & 42 & 55 & 3.67 & 1.72 & 3.20 & 1.56 & 1.40 & 0.29 \\
\hline \multicolumn{9}{|l|}{ Western Europe } \\
\hline Finland $^{\mathrm{a}}$ & 24 & 90 & 3.35 & 1.50 & 3.28 & 1.78 & 0.16 & 0.04 \\
\hline \multicolumn{9}{|l|}{ United Kingdom } \\
\hline UK-Northern Ireland & 56 & 244 & 4.05 & 1.57 & 3.36 & 1.64 & $2.88 * *$ & 0.42 \\
\hline UK-England $^{\mathrm{b}}$ & 82 & 101 & 4.00 & 1.57 & 3.80 & 1.71 & 0.80 & 0.12 \\
\hline Netherlands & 115 & 126 & 3.75 & 1.63 & 3.27 & 1.55 & $2.34 *$ & 0.30 \\
\hline Belgium (Flanders) & 166 & 356 & 3.81 & 1.73 & 3.45 & 1.73 & $2.18^{*}$ & 0.20 \\
\hline France & 55 & 56 & 4.10 & 1.79 & 3.85 & 1.75 & 0.71 & 0.14 \\
\hline Switzerland & 85 & 129 & 3.89 & 1.71 & 3.24 & 1.67 & $2.73 * *$ & 0.37 \\
\hline
\end{tabular}


Table 1. (continued)

\begin{tabular}{|c|c|c|c|c|c|c|c|c|}
\hline Germany $^{\mathrm{b}}$ & 294 & 496 & 3.81 & 1.73 & 3.24 & 1.77 & $4.41 * * *$ & 0.32 \\
\hline Austria $^{\mathrm{b}}$ & 207 & 260 & 3.77 & 1.88 & 3.69 & 1.89 & 0.42 & 0.04 \\
\hline \multicolumn{9}{|l|}{ Eastern Europe } \\
\hline Estonia & 79 & 109 & 3.47 & 1.67 & 3.38 & 1.69 & 0.34 & 0.05 \\
\hline Latvia & 90 & 103 & 4.13 & 1.74 & 3.36 & 1.82 & $3.00 * *$ & 0.43 \\
\hline Lithuania & 47 & 47 & 3.64 & 1.67 & 3.66 & 1.82 & -0.06 & -0.01 \\
\hline Poland & 309 & 537 & 3.50 & 1.93 & 3.17 & 1.85 & $2.42 *$ & 0.17 \\
\hline Czech Republic & 106 & 129 & 3.10 & 1.62 & 2.61 & 1.59 & $2.35 *$ & 0.31 \\
\hline Slovakia & 84 & 100 & 3.58 & 1.67 & 2.92 & 1.74 & $2.60 * *$ & 0.38 \\
\hline Ukraine $^{\mathrm{b}}$ & 100 & 100 & 4.39 & 1.88 & 4.84 & 1.49 & -1.85 & -0.26 \\
\hline Romania & 123 & 128 & 4.24 & 1.84 & 4.15 & 2.06 & 0.38 & 0.05 \\
\hline Serbia & 100 & 100 & 3.63 & 1.76 & 3.07 & 1.75 & $2.26^{*}$ & 0.32 \\
\hline Croatia & 113 & 109 & 3.59 & 1.82 & 3.39 & 1.73 & 0.87 & 0.12 \\
\hline Slovenia & 73 & 109 & 3.63 & 1.63 & 3.07 & 1.40 & $2.47 * *$ & 0.37 \\
\hline \multicolumn{9}{|l|}{ Southern Europe } \\
\hline Portugal & 110 & 142 & 3.51 & 1.80 & 3.17 & 1.71 & 1.53 & 0.19 \\
\hline Spain & 95 & 178 & 3.21 & 1.74 & 2.58 & 1.49 & $3.15^{* *}$ & 0.39 \\
\hline Italy $^{\mathrm{b}}$ & 92 & 108 & 3.05 & 1.69 & 2.69 & 1.82 & 1.48 & 0.21 \\
\hline Malta & 133 & 198 & 3.75 & 1.91 & 3.73 & 1.93 & 0.11 & 0.01 \\
\hline Greece & 47 & 182 & 3.38 & 1.73 & 3.42 & 1.79 & -0.12 & -0.02 \\
\hline Cyprus & 24 & 36 & 4.00 & 1.80 & 3.42 & 1.89 & 1.16 & 0.31 \\
\hline \multicolumn{9}{|l|}{ Middle East } \\
\hline Turkey $^{\mathrm{b}}$ & 206 & 206 & 3.80 & 1.85 & 3.08 & 1.76 & $4.04 * * *$ & 0.39 \\
\hline Lebanon & 124 & 139 & 4.07 & 1.86 & 3.91 & 1.76 & 0.68 & 0.09 \\
\hline Israel & 180 & 214 & 3.66 & 1.64 & 3.31 & 1.66 & $2.10^{*}$ & 0.21 \\
\hline Jordan & 80 & 195 & 3.44 & 1.90 & 3.53 & 2.32 & -0.32 & -0.04 \\
\hline \multicolumn{9}{|l|}{ Africa } \\
\hline Morocco & 93 & 89 & 4.27 & 2.01 & 4.03 & 2.26 & 0.75 & 0.11 \\
\hline Ethiopia $^{\mathrm{b}}$ & 140 & 100 & 4.69 & 1.97 & 5.00 & 2.10 & -1.14 & -0.15 \\
\hline Tanzania, United Republic of & 93 & 43 & 3.30 & 2.05 & 3.78 & 2.38 & -1.19 & -0.22 \\
\hline
\end{tabular}


Table 1. (continued)

\begin{tabular}{|c|c|c|c|c|c|c|c|c|}
\hline Congo, Democratic Republic of the & 126 & 66 & 3.13 & 1.86 & 2.81 & 1.94 & 1.06 & 0.17 \\
\hline Zimbabwe & 100 & 100 & 3.75 & 2.19 & 3.88 & 2.00 & -0.41 & -0.06 \\
\hline Botswana & 97 & 116 & 4.08 & 2.08 & 4.35 & 2.05 & -0.95 & -0.13 \\
\hline South Africa & 81 & 81 & 4.16 & 1.79 & 4.15 & 1.78 & 0.04 & 0.01 \\
\hline \multicolumn{9}{|l|}{ Oceania } \\
\hline Australia & 201 & 288 & 4.03 & 1.53 & 3.90 & 1.52 & 0.94 & 0.09 \\
\hline New Zealand & 116 & 158 & 4.17 & 1.64 & 3.88 & 1.63 & 1.43 & 0.17 \\
\hline Fiji \& Pacific Islands ${ }^{b}$ & 81 & 82 & 4.20 & 1.90 & 4.34 & 2.05 & -0.43 & -0.07 \\
\hline \multicolumn{9}{|l|}{ South/Southeast Asia } \\
\hline India & 100 & 100 & 4.15 & 1.84 & 4.17 & 1.79 & -0.08 & -0.01 \\
\hline Bangladesh & 83 & 62 & 4.92 & 2.17 & 4.69 & 1.90 & 0.64 & 0.11 \\
\hline Malaysia & 50 & 91 & 4.75 & 1.50 & 4.26 & 1.79 & 1.59 & 0.29 \\
\hline Indonesia & 55 & 56 & 4.56 & 1.55 & 4.33 & 1.97 & 0.64 & 0.13 \\
\hline Philippines & 121 & 161 & 4.59 & 1.56 & 4.02 & 1.68 & $2.88 * *$ & 0.35 \\
\hline \multicolumn{9}{|l|}{ East Asia } \\
\hline Hong Kong (China) & 100 & 101 & 4.04 & 1.31 & 3.97 & 1.55 & 0.34 & 0.05 \\
\hline Taiwan & 116 & 93 & 4.09 & 1.74 & 3.85 & 1.71 & 0.99 & 0.14 \\
\hline (South) Korea, Republic of & 195 & 295 & 3.80 & 1.69 & 3.49 & 1.67 & $2.03 *$ & 0.19 \\
\hline Japan & 157 & 102 & 2.78 & 1.56 & 2.29 & 1.31 & $2.64 * *$ & 0.33 \\
\hline Worldwide ISDP Sample: & 7,432 & 10,372 & 3.88 & 1.80 & 3.55 & 1.81 & $12.01 * * *$ & 0.18 \\
\hline
\end{tabular}

Note. Most samples were primarily comprised of college students, some included general members of the community. All samples were convenience samples. Further details on sampling methods within each culture are available from the authors.

${ }^{\mathrm{a}}=$ Community-based sample; ${ }^{\mathrm{b}}=$ Combination of college students and community-based samples.

${ }^{*} p<.05 ; * * p<.01 ; * * * p<.001$. 
members of the community, and two (Finland and Mexico) consisted solely of community members. All samples were convenience samples. Most participants were recruited as volunteers, some received course credit for participation, and others received a small monetary reward for their participation. All samples were administered an anonymous self-report survey, most of which were returned via sealed envelope and/or the usage of a dropbox. Return rates for college student samples tended to be relatively high (around 95\%), though this number was lower in some cultures. Return rates for community samples were around $50 \%$. Not all participants from Chile, Jordan, South Africa, Fiji, India, and Bangladesh received the full ISDP survey, though all samples received the measures used in this paper. Missing data was a problem in some samples, though this was generally restricted to measures that dealt explicitly with sexual desire and infidelitytopics not addressed in this paper. Further details on the sampling and assessment procedures within each of the 62 cultural regions are provided elsewhere (Schmitt et al., in press) and are available from the authors.

\section{Procedure}

All collaborators were asked to administer an anonymous 9-page survey to at least 100 men and 100 women. As seen in Table 1, most collaborators reached this approximate sample size of men and women. Participants were provided with a brief description of the study, including the following written instructions:

This questionnaire is entirely voluntary. All your responses will be kept confidential and your personal identity will remain anonymous. No identifying information is requested on this survey, nor will any such information be added later to this survey. If any of the questions make you uncomfortable, feel free not to answer them. You are free to withdraw from this study at any time for any reason. This series of questionnaires should take about 20 minutes to complete. Thank you for your participation.
The full instructional set provided by each collaborator varied, however, and was adapted to fit the specific culture and type of sample. Details on incentives and cover stories used across samples are available from the authors.

\section{Measures}

Language and translation procedures. In 21 samples the survey was administered in English; it was translated into 29 other languages as well. More specifically, the survey was administered in English to participants from Canada, the United States, the United Kingdom, Malta, Lebanon, all African countries except the Congo, Oceania, the Philippines, and Hong Kong. The survey was administered in Spanish to participants from Spain and all South American countries except Brazil. It was administered in German to those from Switzerland, Germany, and Austria, and in French to those from French Canada, France, and the Congo. Elsewhere it was administered in a variety of other languages indigenous to the regions.

Researchers from cultural regions where English is not the primary language were asked to use a translation/back-translation process and administer the ISDP in the native language. This procedure typically involved the primary collaborator translating the measures into the native language of the participants, and then having a second person back-translate the measures into English. Differences between the original English and the back-translation were discussed, and mutual agreements were made as to the most appropriate translation. This procedure tries to balance the competing needs of making the translation meaningful and naturally readable to the native participants, while preserving the integrity of the original measure and its constructs (Brislin, 1980). Samples from Morocco, Ethiopia, Fiji, the Philippines, and Hong Kong were administered the survey in English, but certain terms and phrases were annotated to clarify what were thought to be confusing words for the participants. The translation of the ISDP survey into the Flemish dialect 
of Dutch used only a translation procedure, as this involved mainly word variant changes from the original Dutch. Finally, pilot studies were conducted in several testing sites, in part to clarify translation and comprehension concerns.

Demographic measure. Each sample was first presented with a demographic measure entitled "Confidential Personal Information." This measure included questions about gender, age, date of birth, weight, height, sexual orientation, current relationship status, socioeconomic status as a child, socioeconomic status now, area in which one was raised (rural, urban, suburban), total number of years of education, current religious affiliation, degree of religiosity, ethnic background, and political attitude (conservative versus liberal). Not all questions were included in all samples (e.g., date of birth was considered too invasive in some cultures; some cultures had no concept of "suburban"), and all collaborators were asked to adapt the demographic questions to obtain the most appropriate demographic variables for their culture (e.g., ethnicity and religious affiliation categories varied across cultures; political attitude terminology varied across cultures).

Romantic attachment measure. All samples were administered the two-dimension/ four-category measure of adult romantic attachment called the Relationship Questionnaire (RQ; Bartholomew \& Horowitz, 1991). This measure of attachment has one single-item secure romantic attachment scale, and three single-item insecure scales including a dismissing romantic attachment. Each single-item scale uses a 7-point Likert-type rating format ranging from $1=$ doesn't describe me to $7=$ very accurately describes me, with 4 as the midpoint of each scale. We used this measure of dismissing romantic attachment because the RQ is relatively brief and has been validated in several studies and because it has been described as useful for examining the relationship of attachment to external cultural criteria (Bartholomew, 1994; Griffin \& Bartholomew, 1994). Although some may consider it a limitation of the current study, single-item scales are increasingly being viewed as psychometrically sound alternatives to longer, more redundant multi-item scales (Barrett \& Paltiel, 1996). As the key analyses in this study are done on data aggregated at the cultural level rather than on the answers of individual respondents, the loss of reliability resulting from a single-item measure is less problematic. The complete RQ dismissing attachment item in English reads: "I am comfortable without close emotional relationships. It is very important to me to feel independent and self-sufficient, and I prefer not to depend on others or have others depend on me."

Other measures of the ISDP. Participants in the ISDP were also asked to complete several measures not used in the present analyses. This included a measure of global selfesteem (Rosenberg, 1965) and a measure of personality traits (Benet-Martinez \& John, 1998). Multiple sexuality measures were administered, including measures of shortterm mating tendencies (Schmitt et al., 2001), the sociosexual orientation inventory (Simpson \& Gangestad, 1991), a survey of human mate-poaching experiences (Schmitt \& Buss, 2001), and the "Sexy Seven" trait measure of sexual self-description (Schmitt \& Buss, 2000).

Archival measures. To test the second and third evolutionary and social role hypotheses, several archival data sets were used. First, there were four measures of high stress environments. The first was pathogen stress load, computed by summing the incidence of seven infectious diseases, including leishmanias, malaria, and leprosy (for computational details, see Gangestad \& Buss, 1993). It was assumed that the higher the level of pathogens, the greater the environmental and reproductive stress experienced by a culture. The second stress measure was data on HIV/AIDS rates 
obtained from United Nations Development Programme (2001). Scores from Serbia and Taiwan were not available. Cultures with high levels of HIV/AIDS were considered under higher stress than those with lower levels. Life expectancy at birth (or mortality rate) was the third stress measure (UN Development Programme). It can be a good indicator of environmental stress and general health of a culture, as it reflects both the overall exposure people have to diseases and environmental dangers, as well as the quality of healthcare a nation provides to help reduce the harsh consequences of disease exposure (again, scores were not available for Serbia or Taiwan). The final stress measure was the Human Development Index, defined as the achievement of a nation in basic human capabilities, including health, longevity, education, and a decent standard of living (UN Development Programme). Those nations with lower levels of human development can be seen as having higher levels of environmental stress. Fertility rates obtained from the United Nations Development Programme were used to test the third evolutionary hypothesis.

To test the second Sex Role Hypothesis, an index of cultural masculinity was obtained from Hofstede's (2001) classic IBM study of attitudes and values. High levels of cultural masculinity are associated with the differential socialization of children and an emphasis on separate social roles and structures among adults, and is highly related to sex-role ideology (Hofstede, 2001). To test the third Sex Role Hypothesis, two measures were employed. The Gender Empowerment Measure (GEM), available for 36 nations, was obtained from the United Nations Human Development Report (UN Development Programme, 2001). The GEM is based on the degree to which women have equal access to economic, political, and decision-making roles in a culture. As noted by Eagly and Wood (1999), the GEM is "a purer indicator of equal participation in economic and political life" (p. 417) than other gender equity measures. The Gender-related
Development Index (GDI) was obtained from the United Nations Human Development Report. The GDI is similar to the Human Development Index in that it is an index of a nation's capability in providing health, education, and welfare to its citizens. However, the GDI penalizes nations if men and women have unequal levels of human development in that nation (UN Development Programme, 2001).

\section{Results and Discussion}

Are men universally more dismissing than women across cultures?

A primary objective of this research was to evaluate the prediction of both Evolutionary and Social Role theories that gender differences in the dismissing form of romantic attachment should consistently emerge across a diverse range of cultures. Listed in Table 1 are the mean levels of dismissing romantic attachment for men and women from the 62 cultural regions of the ISDP. At first glance, men's and women's dismissing romantic attachment levels appear to vary considerably across cultures, with the highest levels of men's dismissing attachment in Bangladesh $(M=4.92)$ and the lowest levels in Argentina $(M=2.76)$. For men, the variability within cultures of dismissing attachment - expressed in standard deviations - averaged 1.80. For women, the highest level of dismissing romantic attachment was found in Ethiopia $(M=5.00)$ and the lowest level in Argentina $(M=2.21)$. Similar to men, for women the variability within cultures averaged around 1.80. Overall, we found a strong positive association among men's and women's dismissing attachment levels across the 62 cultures. Using averages of the 56 nations, men's level of dismissing romantic attachment levels correlated positively with women's level of dismissing romantic attachment, $r(54)=+0.87$, $p<.001$.

Even though men's and women's scores were positively correlated across cultures, small to moderate gender differences in dismissing romantic attachment emerged in 
most cultures. As seen in Table 1, we computed effect sizes $(d)$ within each cultural region as an expression of the magnitude of the difference between men's and women's levels of dismissing romantic attachment. Previous research (e.g., Bartholomew \& Horowitz, 1991) found that gender differences in dismissing attachment were moderate in size (around $d=0.50$ ). The five largest gender differences in dismissing attachment that we found were in USA-Hawaii $(d=0.43)$, Latvia $(d=0.43)$, Northern Ireland $\quad(d=0.42)$, Chile $(d=0.39)$, and Spain $(d=0.39)$. All of these differences approached a moderate magnitude of effect (Cohen, 1988), similar to previous research findings (Bartholomew \& Horowitz). However, for most cultural regions gender differences were small in magnitude (around $d=0.20$ ), with only 43 of 62 cultural regions $(69 \%)$ possessing a gender difference greater than $d=0.10$. Moreover, in only 23 of 62 cultures (37\%) did the observed gender differences reach the level of statistical significance, though inadequate sample sizes may have obscured significance levels of small effect sizes in some regions. For example, with statistical power $(\beta)$ set at 0.80 and statistical significance $(\alpha)$ at 0.05 , to ensure that a difference of $d=0.20$ would be found statistically significant, a sample size of more 300 men and 300 women would have been necessary (Kirk, 1999). Our samples averaged approximately 100 men and 100 women, suggesting that we may have sampled too few participants to always capture small $(d=0.20)$ gender differences as statistically significant. A few cultures possess the opposite of the predicted pattern, with women slightly more dismissive than men (e.g., Ukraine, Ethiopia, Tanzania, and Botswana). However, these differences are neither significant nor do the findings approach moderate levels of magnitude. Overall, these findings lead us to tentatively conclude that greater male dismissiveness is a "near universal" of human nature (Brown, 1991; Gaulin, 1997), but that some features of culture seem to attenuate its expression.
Using a $2 \times 10$ factorial design with gender (male, female) and the 10 "world region" groupings shown in Table 1 as independent variables, we found a main effect of gender on dismissing attachment such that men were significantly more dismissing than women, $F(1,17,614)=90.75, \quad p<.001$, $\eta^{2}=0.01$. However, the magnitude of this effect as indexed by "partial eta squared" was small. ${ }^{1}$ According to Cohen (1988), partial eta squared $\left(\eta^{2}\right)$ is considered small if 0.01 , medium if 0.06 , and large above 0.14 . We also found that world region has a small but significant main effect, $F(9$, $17,614)=47.59, p<.001, \eta^{2}=0.02$, and we found that gender significantly interacts with world region, $F(9,17,614)=4.26$, $p<.001, \eta^{2}=0.002$. As shown in Figure 1, gender differences in dismissive romantic attachment are not evident in Africa, and the effects of gender are smaller in Oceania and East Asia than in other world regions. These regional differences are all significant according to multiple post hoc statistical analyses (e.g., Tukey's HSD). From these results it must be concluded that it is only a "near universal" of human psychology for men to be more dismissing in romantic attachment orientation than women. Men are more dismissing than women in almost all cultures, but these differences are usually quite small in magnitude. Evolutionary Hypothesis 1 and Social Role Hypothesis 1 , therefore, received only partial support from our ISDP analyses.

What causes gender differences in dismissing romantic attachment to vary across cultures?

Evolutionary Hypothesis 2 stated that gender differences in dismissing romantic attachment should be lower in cultures with

1. Using a similar analytic approach, we found signficant main effects of gender such that men are more secure, $F(1,17,594)=13.42, p<.001$, $\eta^{2}=0.001$, and preoccupied, $F(1,17,603)=43.34$, $p<.001, \eta^{2}=0.002$, than women. In contrast, women are signficantly more fearful than men, $F(1,17,589)=69.65, p<.001, \eta^{2}=0.004$. However, these effect sizes are trivial in magnitude compared to the observed gender differences in dismissing romantic attachment. 


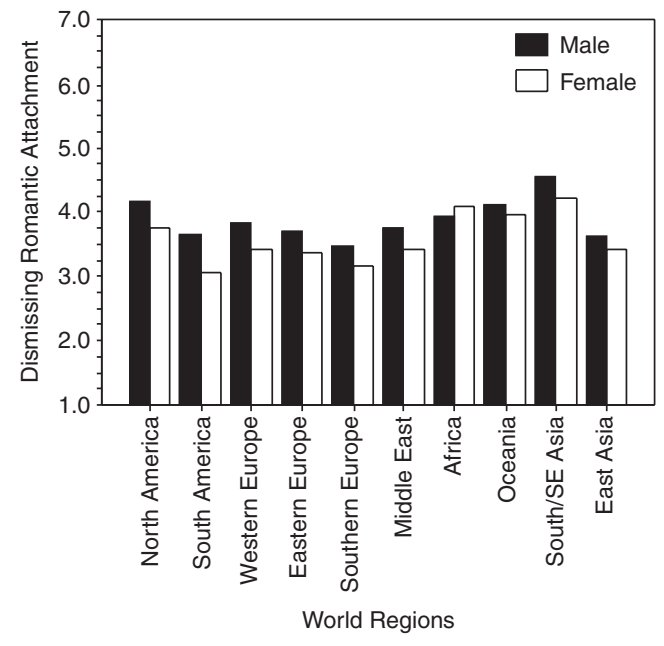

Figure 1. Dismissing romantic attachment scores of men and women across the 10 world regions of the International Sexuality Description Project. high-stress environments. We examined Evolutionary Hypothesis 2 by relating our observed gender differences in dismissing romantic attachment to four sociocultural indexes: pathogen stress load, HIV/AIDS rates, life expectancies, and the Human Development Index. As shown at the top of Table 2, the pathogen stress load is unrelated to the difference between men's and women's levels of dismissing attachment, $r(18)=-0.01$. Thus, this finding failed to support Evolutionary Hypothesis 2. However, support for the hypothesis was found in the other three indexes.

As predicted, in nations with higher stress levels (i.e., higher HIV/AIDS rates) the difference between men's and women's dismissing romantic attachment is reduced, $r(52)=-0.43, p<.001$. Life expectancy at birth is also strongly correlated with the

Table 2. Dismissing romantic attachment correlated with sociocultural characteristics

\begin{tabular}{|c|c|c|c|}
\hline \multirow[b]{2}{*}{ Sociocultural characteristics } & \multicolumn{3}{|c|}{ Dismissing romantic attachment } \\
\hline & Men & Women & $\begin{array}{l}\text { Gender } \\
\text { difference }\end{array}$ \\
\hline \multicolumn{4}{|l|}{ Evolutionary psychology predictors } \\
\hline $\begin{array}{l}\text { Pathogen load }(n=20) \\
\quad \text { (Gangestad \& Buss, 1993) }\end{array}$ & -0.05 & 0.01 & -0.01 \\
\hline $\begin{array}{l}\text { HIV/AIDS rate among adults }(n=54) \\
\text { (United Nations Development Programme, 2001) }\end{array}$ & 0.08 & $0.28 *$ & $-0.43 * * *$ \\
\hline $\begin{array}{l}\text { Life expectancy at birth }(n=54) \\
\quad(\text { United Nations Statistics Division, 2001) }\end{array}$ & $-0.29 *$ & $-0.46^{* * *}$ & $0.47 * * *$ \\
\hline $\begin{array}{l}\text { Human development index }(n=54) \\
\quad \text { (United Nations Development Programme, 2001) }\end{array}$ & $-0.31^{*}$ & $-0.48 * * *$ & $0.48 * * *$ \\
\hline $\begin{array}{l}\text { National fertility rate }(n=54) \\
\quad \text { (United Nations Development Programme, 2001) }\end{array}$ & $0.24 *$ & $0.38 * *$ & $-0.38 * *$ \\
\hline \multicolumn{4}{|l|}{ Social role theory predictors } \\
\hline $\begin{array}{l}\text { Cultural masculinity }(n=49) \\
\quad \text { (Hofstede, 2001) }\end{array}$ & -0.06 & -0.09 & 0.12 \\
\hline $\begin{array}{l}\text { Gender empowerment measure }(n=36) \\
\quad(\text { United Nations Development Programme, 2001) }\end{array}$ & -0.21 & -0.19 & 0.08 \\
\hline $\begin{array}{l}\text { Gender development index }(n=53) \\
\quad(\text { United Nations Development Programme, 2001) }\end{array}$ & $-0.31^{*}$ & $-0.48 * * *$ & $0.49 * * *$ \\
\hline
\end{tabular}

Note. Correlations in the first two columns represent the nation-level dismissing attachment means of men and women, respectively, related to sociocultural indicator variables. Correlations in the "Gender difference" column represent the magnitude of nation-level gender differences $(d)$ related to sociocultural indicator variables.

${ }^{*} p<.05 ; * * p<.01 ; * * * p<.001$. 




Figure 2. Gender differences (d) in dismissing romantic attachment related to life expectancy at birth across 54 nations.

difference between men's and women's levels of dismissing attachment, $r(52)=+0.47, p<.001$ (see Figure 2). This relationship suggests that as environmental harshness and stress increases (indicated by a lower life expectancy), the gender difference in dismissing attachment decreases, as predicted. Finally, with the fourth indicator of stress, the lower the human development index for a country, the smaller the difference between men's and women's dismissing romantic attachment, $r(52)=+0.48$, $p<.001$, just as predicted by Evolutionary Hypothesis 2.

It is also worth noting that the relationship between life expectancy and dismissing attachment levels is, as predicted by Chisholm (1996), strongly negative in women, $r(52)=-0.46, p<.001$. Moreover, the strength of this relationship appears to be somewhat lower in men, $r(52)=-0.29$, $p<.05$ (see Table 2). Although in this case the difference between men's and women's correlations fails to reach significance using Fisher's $r^{\prime}$ to $z$ transformation, $z(52)=1.00$, $p=.16$, this general trend may still be seen as in line with the notion that variations in women's dismissing attachment are what drive the shift in gender difference across cultures.

Evolutionary Hypothesis 3 stated that gender differences in dismissing romantic attachment should be lower in cultures with higher fertility rates. We correlated gender differences in dismissing romantic attachment with the national fertility rate of 52 nations for which data were provided by the United Nations (UN Development Programme, 2001). Fertility rates were recorded such that higher levels indicate more children are born per female in a culture. As shown in Table 2, we found a significant negative association between fertility rates and the magnitude of gender 
difference between men's and women's dismissing attachment, $r(52)=-0.38, p<.01$. This confirms Evolutionary Hypothesis 3 in that cultures with higher fertility levels tend to have reduced differences between men's and women's dismissing romantic attachment levels. We also found that fertility rates were positively associated with dismissing romantic attachment in men, $r(52)=0.24, p<.05$, and slightly more so in women, $r(52)=0.38, p<.01$. Again, this trend seems to support the view that variation in dismissing attachment gender differences across cultures is more strongly driven by variations in women's level of dismissing romantic attachment.

\section{What aspects of social structure cause gender differences in dismissing romantic attachment to vary across cultures?}

Social Role Hypothesis 2 stated that gender differences in dismissing romantic attachment should be lower in cultures with modern or more progressive sex-role ideologies. As shown in Table 2, we tested Social Role Hypothesis 2 by correlating gender differences in dismissing romantic attachment with the overall level of cultural masculinity across the 49 nations that were part of both Hofstede's (2001) IBM data set and the current ISDP survey. We found that gender differences in dismissive attachment are unrelated to cultural masculinity levels, $r(47)=+0.12, p=.21$. The correlation is in the predicted direction, however, with higher cultural masculinity scores associated with larger gender differences. Overall, Social Role Hypothesis 2 received little empirical support from our study.

Social Role Hypothesis 3 stated that gender differences in dismissing romantic attachment should be lower in cultures where women have access to political and economic power. We related gender differences in dismissive attachment to an index of political and economic equality across nations, the Gender Empowerment Measure (UN Development Programme, 2001). As shown in Table 2, the GEM is not significantly associated with gender differences in dismissing attachment. The correlation that was found is in the positive direction, $r(34)=+0.08, p=.33$, suggesting that if a relationship does exist, women gaining more access to economic and political power is associated with greater differences between men and women. Thus, our findings are not supportive of Social Role Hypothesis 3.

A second test of Social Role Hypothesis 3 came from relating gender differences in dismissing romantic attachment to the level of gender development across nations. As seen in Table 2, we found that the differences in men's and women's levels of dismissing romantic attachment tended to increase as the GDI increased, $r(51)=+0.49, p<.001$. Because the differences between men and women increase as women gain economic equality, our findings seemed to run directly counter to Social Role Hypothesis 3.

One limitation of findings reported in Table 2 is that the two perspectives, evolutionary and social role theory, were evaluated using varying numbers of nations. In order to more directly contrast the evolutionary and social role hypotheses, we conducted a series of partial correlations using common subsets of cultures. For example, we correlated life expectancy scores with gender differences in dismissing attachment, after partialling out the effects of cultural masculinity (we highlight cultural masculinity because it provided the most support for social role hypotheses). This partial correlation, based on the 46 nations for which we had all three indexes, was $r(42)=+0.49$, $p<.001$. This finding suggests that Evolutionary Hypothesis 2 is equally supported after the effects of cultural masculinity were partialled out. Conversely, we correlated cultural masculinity with gender differences in dismissing attachment after partialling out the effects of life expectancy. We found partialling out the effects of life expectancy reduced the cultural masculinity correlation to $r(42)=+0.09, p=.28$. Similar results were obtained from computing partial correlations and stepwise regressions on all other evolutionary and social role 
predictors. Overall, these findings suggest that the social role variables are relatively poor predictors of gender differences in dismissing romantic attachment and do not add further incremental variance beyond that of the more powerful evolutionary predictors.

\section{Limitations and future research directions}

The survey responses that form the basis of this study are, in many ways, of limited value. For one, the reliance on self-report as the sole means of assessment is a serious limitation, particularly with the sensitive nature of romantic attachment styles (Whitely, 1996). It is true that anonymity tends to increase the validity of sex-related surveys, especially when compared to faceto-face interviews (Andersen \& Broffitt, 1988). Nevertheless, even with guarantees of anonymity the cross-cultural nature of the ISDP raises additional questions about survey response veridicality (Brislin, 1993). Any observed cultural differences, for example, may be due not only to a real cultural disparity on attachment, but also to inappropriate translations, biased sampling, or the nonidentical response styles prevalent in various cultures (van de Vijver \& Leung, 2000).

The concerns about sampling raise the additional issue of generalizability. The convenience sampling techniques utilized in the ISDP seriously limit the representativeness of our national attachment profiles. Because the ISDP samples were primarily college students, any generalizations beyond college-aged populations would be inappropriate. On the other hand, because all nations were represented by college-aged samples, any differences between samples will tend to elucidate the effects of culture, and not other age-related demographic confounds. Ultimately, future research taking factors such as sampling and response biases into account will be needed to fully verify the psychometric value of nationlevel scores on the Relationship Questionnaire.
Another limitation involves the representativeness of high-stress cultures. For example, in the ISDP samples from Africa, most participants were college students. Unlike many Western cultures, college students are rather unrepresentative of national African populations. Indeed, African students from Botswana, the Democratic Republic of the Congo, Ethiopia, and Zimbabwe may constitute a subportion of their cultures that is especially exempt from high rates of ecological stressors. Future research in which truly representative samples from a wider range of high-stress cultures will help to more accurately relate United Nation databases of stress to large-scale anonymous sex surveys.

\section{Conclusion}

We conclude from our ISDP findings that gender differences in dismissing romantic attachment are only a "near universal" of human culture. In Western cultures, previous research had profiled men as significantly more dismissing than women (e.g., Bartholomew \& Horowitz, 1991). We encountered this general trend among Western cultures as well, but we also revealed that in non-Western cultures men are sometimes only slightly more dismissing than women. In some African and Oceanic cultures-including Ethiopia, Tanzania, Botswana, Zimbabwe, and Fiji-women are slightly more dismissing than men. These findings seem to run counter to the expectations of evolutionary psychology and social role theories which predicted gender differences in dismissing romantic attachment should be culturally universal. Still, most cultures display small to moderate gender differences in dismissing romantic attachment, suggesting that greater male dismissiveness is a near universal of human psychology (Brown, 1991). Consequently, our efforts shifted to understanding what features of culture might accentuate or attenuate gender differences in romantic dismissiveness.

Evolutionary psychological theories of romantic attachment and human mating 
(Belsky et al., 1991; Chisholm, 1996; Gangestad \& Simpson, 2000) have suggested that in cultures where environmental and reproductive stressors are relatively high, women should tend to engage in more short-term mating, and presumably women should tend to develop more dismissing romantic attachment orientations (Kirkpatrick,1998). In the ISDP, short-term mating is associated with high levels of dismissing attachment (Schmitt, 2003b). In combination with men's preferential tendency toward dismissing romantic attachment and short-term mating in general (Buss \& Schmitt, 1993; Schmitt et al., 2001), this led to the expectation that men's and women's dismissing attachment orientations will converge and become more similar in cultures with high-stress reproductive environments. We found some support for these hypotheses by relating the magnitude of gender differences in dismissing attachment to sociocultural indicators from previous research. For example, we confirmed that in cultures with low life expectancy, poor human development, and high fertility rates (an index of reproductive stress), gender differences in dismissing attachment are attenuated, presumably because women become more similar to men in short-term mating tendencies and express concomitantly higher levels of dismissing romantic attachment.

Social role theory led to the prediction that gender differences should be minimized in cultures with more modern sex-role ideologies. Because social role theories posit that gender differences come from the strong gender roles that men and women are channeled into, more traditional sex-role ideologies should be associated with larger gender differences. We found little evidence in support of this hypothesis. In most instances, the trend ran counter to this theoretical perspective. Greater political and economic equality, for example, is at times associated with larger gender differences in dismissing attachment across cultures. This perplexing finding is not unique to the ISDP dataset, however. Several cross-cultural studies (e.g., Costa et al., 2001; Williams \& Best, 1990) have shown that more progressive sex-role cultures tend to have larger gender differences in self-perceptions. For instance, in a recent study of personality traits across 26 cultures, it was noted that "the social role model would have hypothesized that gender differences would be attenuated in progressive countries, when in fact they were magnified" (Costa et al., 2001, p. 329).

Future research is needed to understand how a culture's tendency to treat men and women more similarly unexpectedly leads to greater differences between men and women. One speculation is that in cultures where men and women are more highly differentiated, they fail to even compare themselves across genders when completing self-report surveys. In cultures where men and women are free to inhabit different social roles, on the other hand, people are more likely to compare themselves to both genders and sex differences are thereby more likely to surface. For example, Costa and his colleagues (2001) speculated that, "in traditional cultures, where clear sex role differences are prescribed, self-descriptions are based on comparisons of the self with others of the same gender...in modern cultures men and women may compare themselves to others of both genders, and thus reveal true gender differences" (p. 329).

In sum, we found that gender differences in dismissing romantic attachment are not a pancultural universal. In a few cultures, women appear equal to men in romantic dismissiveness. In most cultures, when men do prove more dismissing than women, the difference is usually only small in magnitude. We also found that variation in gender differences across cultures is associated with several sociocultural characteristics. Specifically, men and women are more similar in cultures with higher mortality, fewer resources, and higher fertility rates. These findings are in accord with some evolutionary theories of romantic attachment and human mating strategies, though not all findings support the evolutionary psychology perspective. We failed to find much support for the social role perspective, in that men's and women's economic equality 
is unassociated with gender differences in dismissing romantic attachment. Future analyses in which the findings presented here are related to other sociocultural characteristics may help to disentangle the complex relationships among romantic attachment, human mating strategies, and sex-role ideologies.

\section{References}

Ainsworth, M. D. S., Blehar, M., Waters, E., \& Wall, S. (1978). Patterns of attachment: A psychological study of the strange situation. Hillsdale, NJ: Erlbaum.

Alexander, R. D. (1990). Epigenetic rules and Darwinian algorithms: The adaptive study of learning and development. Ethology and Sociobiology, 11, 1-63.

Allen, J. P., \& Land, D. (1999). Attachment in adolescence. In J. Cassidy \& P. R. Shaver (Eds.), Handbook of attachment (pp. 319-335). New York: Guilford.

Andersen, B. L., \& Broffitt, B. (1988). Is there a reliable and valid self-report measure of sexual behavior? Archives of Sexual Behavior, 17, 509-525.

Barrett, P. T., \& Paltiel, L. (1996). Can a single item replace an entire scale? POP vs the OPQ 5.2. Selection and Development Review, 12, 1-4.

Bartholomew, K. (1990). Avoidance of intimacy: An attachment perspective. Journal of Social and Personal Relationships, 7, 147-178.

Bartholomew, K. (1994). Assessment of individual differences in adult attachment. Psychological Inquiry, 5, 23-27.

Bartholomew, K., \& Horowitz, L. M. (1991). Attachment styles in young adults: A test of a fourcategory model. Journal of Personality and Social Psychology, 61, 226-244.

Belsky, J. (1999). Modern evolutionary theory and patterns of attachment. In J. Cassidy \& P. R. Shaver (Eds.), Handbook of attachment (pp. 141-161). New York: Guilford.

Belsky, J., Steinberg, L., \& Draper, P. (1991). Childhood experience, interpersonal development, and reproductive strategy: An evolutionary theory of socialization. Child Development, 62, 647-670.

Bem, S. L. (1974). The measurement of psychological androgyny. Journal of Consulting and Clinical Psychology, 42, 155-162.

Bem, S. L. (1993). The lenses of gender. New Haven, CT: Yale University Press.

Benet-Martinez, V., \& John, O. P. (1998). Los Cinco Grandes across cultures and ethnic groups: Multitrait-multimethod analyses of the Big Five in Spanish and English. Journal of Personality and Social Psychology, 75, 729-750.

Bogaert, A. F., \& Sadava, S. (2002). Adult attachment and sexual behavior. Personal Relationships, 9, 191-204.

Bowlby, J. (1969/1982). Attachment and loss: Vol. I. Attachment. New York: Basic Books.

Bowlby, J. (1988). A secure base: Parent-child attachment and healthy human development. New York: Basic Books.

Brennan, K. A., Clark, C. L., \& Shaver, P. R. (1998). Self-report measurement of adult attachment: An integrative overview. In J. A. Simpson \& W. S. Rholes (Eds.), Attachment theory and close relationships (pp. 46-76). New York: Guilford.
Brennan, K. A., \& Shaver, P. R. (1995). Dimensions of adult attachment, affect regulation, and romantic relationship functioning. Personality and Social Psychology Bulletin, 21, 267-283.

Brislin, R. W. (1980). Translation and content analysis of oral and written material. In H. C. Triandis \& J. W. Berry (Eds.), Handbook of cross-cultural psychology (Vol. 1, pp. 389-444). Boston: Allyn and Bacon.

Brislin, R. (1993). Understanding culture's influence on behavior. Fort Worth, TX: Harcourt Brace Jovanovich.

Brody, L. R., \& Hall, J. A. (1993). Gender and emotion. In M. Lewis \& J. M. Haviland (Eds.), Handbook of emotions (pp. 447-460). New York: Guilford.

Brown, D. E. (1991). Human universals. New York: McGraw-Hill, Inc.

Burton, L. M. (1990). Teenage childbearing as an alternative life-course strategy in multigenerational black families. Human Nature, 1, 123-144.

Buss, D. M. (1989a). Conflict between the sexes: Strategic interference and the evocation of anger and upset. Journal of Personality and Social Psychology, 56, 735-747.

Buss, D. M. (1989b). Sex differences in human mate preferences: Evolutionary hypotheses tested in 37 cultures. Behavioral and Brain Sciences, 12, 1-49.

Buss, D. M. (1994). The evolution of desire. New York: Basic Books.

Buss, D. M., \& Schmitt, D. P. (1993). Sexual strategies theory: An evolutionary perspective on human mating. Psychological Review, 100, 204-232.

Chisholm, J. S. (1996). The evolutionary ecology of attachment organization. Human Nature, 7, 1-38.

Chisholm, J. S. (1999). Steps to an evolutionary ecology of the mind. In A. L. Hinton (Ed.), Biocultural approaches to the emotions (pp. 117-149). Cambridge, UK: Cambridge University Press.

Cohen, J. (1988). Statistical power analysis for the behavioral sciences (2nd ed.). Hillsdale, NJ: Erlbaum.

Collins, N., \& Read, S. (1990). Adult attachment relationships, working models and relationship quality in dating couples. Journal of Personality and Social Psychology, 58, 644-683.

Collins, N., \& Read, S. (1994). Cognitive representations of attachment: The structure and function of internal working models. In K. Bartholomew \& D. Perlman (Eds.), Advances in personal relationships (Vol. 5, pp. 53-90). London: Jessica Kingsley.

Costa, P. T., Jr., Terracciano, A., \& McCrae, R. R. (2001). Gender differences in personality traits across cultures: Robust and surprising findings. Journal of Personality and Social Psychology, 81, $322-331$.

Cronk, L. (1999). That complex whole: Culture and the evolution of human behavior. Boulder, CO: Westview. 
Dozier, M., Stovall, K. C., \& Albus, K. E. (1999). Attachment and psychopathology in adulthood. In J. Cassidy \& P. R. Shaver (Eds.), Handbook of attachment (pp. 497-519). New York: Guilford.

Draper, P., \& Harpending, H. (1982). Father absence and reproductive strategy: An evolutionary perspective. Journal of Anthropological Research, 38, 255-273.

Eagly, A. H. (1987). Sex differences in social behavior: A social-role interpretation. Hillsdale, NJ: Erlbaum.

Eagly, A. H., \& Wood, W. (1999). The origins of sex differences in human behavior: Evolved dispositions versus social roles. American Psychologist, $54,408-423$.

Eibl-Eibesfeldt, I. (1989). Human ethology. New York: Aldine de Gruyter.

Ellis, B. J., McFadyen-Ketchum, S., Dodge, K. A., Pettit, G. S., \& Bates, J. E. (1999). Quality of early family relationships and individual differences in the timing of pubertal maturation in girls: A longitudinal test of an evolutionary model. Journal of Personality and Social Psychology, 77, 387-401.

Feeney, J. A. (1994). Attachment style, communication patterns, and satisfaction across the life cycle of marriage. Personal Relationships, 1, 333-348.

Feeney, J. A., \& Noller, P. (1996). Adult attachment. Thousand Oaks, CA: Sage.

Feeney, J. A., Noller, P., \& Patty, J. (1993). Adolescents' interactions with the opposite sex: Influence of attachment style and gender. Journal of Adolescence, 16, 169-186.

Feingold, A. (1994). Gender differences in personality: A meta-analysis. Psychological Bulletin, 116, 429-456.

Gangestad, S. W. (2001). Adaptive design, selective history, and women's sexual motivations. In J. A. French, A. C. Kamil, \& D. W. Leger (Eds.), Evolutionary psychology and motivation (pp. 37-74). Lincoln: University of Nebraska Press.

Gangestad, S. W., \& Buss, D. M. (1993). Pathogen prevalence and human mate preferences. Ethology and Sociobiology, 14, 89-96.

Gangestad, S. W., \& Simpson, J. A. (2000). The evolution of human mating: Trade-offs and strategic pluralism. Behavioral and Brain Sciences, 23, 573-587.

Gaulin, S. J. C. (1997). Cross-cultural patterns and the search for evolved psychological mechanisms. In G. R. Bock \& G. Cardew (Eds.), Characterizing human psychological adaptations (pp. 195-207). Chichester, England: Wiley.

Geary, D. C. (1998). Male, female: The evolution of human sex differences. Washington, DC: American Psychological Association.

George, C., \& Solomon, J. (1999). Attachment and caregiving: The caregiving behavioral system. In J. Cassidy \& P. R. Shaver (Eds.), Handbook of attachment (pp. 649-670). New York: Guilford.

Greenberg, M. T. (1999). Attachment and psychopathology in childhood. In J. Cassidy \& P. R. Shaver (Eds.), Handbook of attachment (pp. 469-496). New York: Guilford.

Greiling, H. \& Buss, D. M. (2000). Women's sexual strategies: The hidden dimension of short-term mating. Personality and Individual Differences, 28, 929-963.
Griffin, D., \& Bartholomew, K. (1994). Models of self and other: Fundamental dimensions underlying measures of adult attachment. Journal of Personality and Social Psychology, 67, 430-445.

Harvey, P. H., \& Clutton-Brock, T. H. (1985). Life history variation in primates. Evolution, 39, 559-581.

Hazan, C., \& Shaver, P. R. (1987). Romantic love conceptualized as an attachment process. Journal of Personality and Social Psychology, 52, 511-524.

Hazan, C., \& Zeifman, D. (1999). Pair bonds as attachments: Evaluating the evidence. In J. Cassidy \& P. R. Shaver (Eds.), Handbook of attachment (pp. 336-354). New York: Guilford.

Hofstede, G. (1998). Masculinity and femininity: The taboo dimension of national cultures. Thousand Oaks, CA: Sage.

Hofstede, G. (2001). Culture's consequences. Thousand Oaks, CA: Sage.

Hrdy, S. B. (1981). The woman that never evolved. Cambridge, MA: Harvard University Press.

Kasser, T., \& Sharma, Y. S. (1999). Reproductive freedom, educational equality, and females' preference for resource-acquisition characteristics in mates. Psychological Science, 10, 374-377.

Keller, H. (1990). Evolutionary approaches. In J. W. Berry, Y. H. Poortinga, \& J. Pandey (Eds.), Handbook of cross-cultural psychology, 2nd ed. (Vol. 1, pp. 215-255). Boston: Allyn and Bacon.

Kenrick, D. T., Sadalla, E. K., Groth, G., \& Trost, M. R. (1990). Evolution, traits, and the stages of human courtship: Qualifying the parental investment model. Special issue: Biological foundations of personality: evolution, behavioral genetics, and psychophysiology. Journal of Personality, 58, 97-116.

Kirk, R. E. (1999). Statistics: An introduction. Fort Worth, TX: Harcourt Brace.

Kirkpatrick, L. A. (1998). Evolution, pair-bonding, and reproductive strategies: A reconceptualization of adult attachment. In J. A. Simpson \& W. S. Rholes (Eds.), Attachment theory and close relationships (pp. 353-393). New York: Guilford.

Kirkpatrick, L. A. (1999). Attachment and religious representations and behavior. In J. Cassidy \& P. R. Shaver (Eds.), Handbook of attachment (pp. 803-822). New York: Guilford.

Kirkpatrick, L. A., \& Davis, K. E. (1994). Attachment style, gender, and relationship stability: A longitudinal analysis. Journal of Personality and Social Psychology, 66, 502-512.

Kirkpatrick, L. A., \& Hazan, C. (1994). Attachment styles and close relationships: A four year prospective study. Personal Relationships, 1, 123-142.

Klohnen, E. C., \& John, O. P. (1998). Working models of attachment: A theory-based prototype approach. In J. A. Simpson \& W. S. Rholes (Eds.), Attachment theory and close relationships (pp. 115-140). New York: Guilford.

Lancaster, J. B. (1989). Evolutionary and crosscultural perspectives on single-parenthood. In R. W. Bell \& N. J. Bell (Eds.), Interfaces in psychology (pp. 63-72). Lubbock: Texas Tech University Press.

Lonner, W. J. (1980). The search for psychological universals. In H. C. Triandis \& W. W. Lambert (Eds.), Handbook of cross-cultural psychology (Vol. 1, pp. 143-204). Boston: Allyn \& Bacon. 
Low, B. S. (1989). Cross-cultural patterns in the training of children: An evolutionary perspective. Journal of Comparative Psychology, 103, 311-319.

Low, B. S. (1990). Marriage systems and pathogen stress in human societies. American Zoologist, 30, 325-339.

Low, B. S. (2000). Why sex matters. Princeton, NJ: Princeton University Press.

Mead, M. (1935). Sex and temperament in three primitive societies. New York: Morrow.

Mealey, L. (2000). Sex differences: Developmental and evolutionary strategies. San Diego, CA: Academic Press.

Munroe, R. L., \& Munroe, R. H. (1997). A comparative anthropological perspective. In J. W. Berry, Y. H. Poortinga, \& J. Pandey (Eds.), Handbook of crosscultural psychology, (2nd ed., Vol. 1, pp. 171-213). Boston: Allyn and Bacon.

Pasternak, B., Ember, C., \& Ember, M. (1997). Sex, gender, and kinship: A cross-cultural perspective. Upper Saddle River, NJ: Prentice Hall.

Quinn, N. (1977). Anthropological studies on women's status. Annual Review of Anthropology, 6, 181-225.

Rholes, W. S., Simpson, J. A., \& Blakely, B. S. (1995). Adult attachment styles and mothers' relationships with their young children. Personal Relationships, 2, 35-54.

Rholes, W. S., Simpson, J. A., \& Stevens, J. G. (1998). Attachment orientations, social support, and conflict resolution in close relationships. In J. A. Simpson \& W. S. Rholes (Eds.), Attachment theory and close relationships (pp. 166-188). New York: Guilford.

Rosenberg, M. (1965). Society and the adolescent selfimage. Princeton, NJ: Princeton University Press.

Scharfe, E., \& Bartholomew, K. (1994). Reliability and stability of adult attachment patterns. Personal Relationships, 1, 23-43.

Schmitt, D. P. (2003a). Is short-term mating the result of insecure attachment? A test of competing evolutionary perspectives. Manuscript submitted for publication.

Schmitt, D. P. (2003b). Sociosexuality from Argentina to Zimbabwe, a 48-nation study: Evolutionary and social role perspectives on sex, culture, and the strategies of human mating. Manuscript submitted for publication.

Schmitt, D. P. (2003c). Short-term mating and romantic attachment across 52 nations: Where are the connections? Manuscript submitted for publication.

Schmitt, D. P., Alcalay, L., Allensworth, M., Allik, J., Ault, L., Austers, I., Bennett, K. L., Bianchi, G., Boholst, F., Borg Cunen, M. A., Braeckman, J., Brainerd Jr., E. G., Caral, L. G. A., Caron, G., Casullo, M. M., Cunningham, M., Daibo, I., De Backer, C., Diaz-Loving, R., Diniz, G., Durkin, K., Echegaray, M., Eremsoy, E., Euler, H. A., Falzon, R., Fisher, M. L., Fowler, R., Fry, D. P., Fry, S. F., Ghayur, M. A., Giri, V. N., Golden, D. L., Grammer, K., Grimaldi, L., Halberstadt, J., Haque, S., Hefer, E., Herrera, D., Hertel, J., Hitchell, A., Hoffman, H., Hradilekova, Z., Hudek-Kene-evi, J., Huffcutt, A., Jaafar, J., Jankauskaite, M., Kabangu-Stahel, H., Kardum, I., Khoury, B., Kwon, H., Laidra, K., Laireiter, A., Lakerveld, D., Lampert, A., Lauri, M., Lavallée, M., Lee, S., Leung, L. C., Locke, K. D.,
Locke, V., Luksik, I., Magaisa, I., Marcinkeviciene, J., Mata, A., Mata, R., McCarthy, B., Mills, M. E., Mkhize, N. J., Moreira, J., Moreira, S., Moya, M., Munyea, M., Noller, P., Olimat, H., Opre, A., Panayiotou, A., Petrovic, N., Poels, K., Popper, M., Poulimenou, M., P'yatokh, V., Raymond, M., Reips, U., Reneau, S. E., Rivera-Aragon, S., Rowatt, W. C., Ruch, W., Rus, V. S., Safir, M. P., Sambataro, F., Sandnabba, K. N., Schleeter, R., Schulmeyer, M. K., Schütz, A., Scrimali, T., Shackelford, T. K., Sharan, M. B., Shaver, P. R., Sichona, F., Simonetti, F., Sineshaw, T., Sookdew, R., Speelman, T., Sümer, H. C., Sümer, N., Supekova, M., Szlendak, T., Taylor, R., Timmermans, B., Tooke, W., Tsaousis, I., Tungaraza, F. S. K., Turner, A., Vandermassen, G., Vanhoomissen, T., Van Overwalle, F., Van Wesenbeek, I., Vasey, P. L., Verissimo, J., Voracek, M., Wan, W. W. N., Wang, T., Weiss, P., Wijaya, A., Woertment, L., Youn, G., \& Zupanèiè, A. (in press). Patterns and universals of adult romantic attachment across 62 cultural regions: Are models of self and other pancultural constructs? Journal of Cross-Cultural Psychology.

Schmitt, D. P., \& Buss, D. M. (2000). Sexual dimensions of person description: Beyond or subsumed by the Big Five? Journal of Research in Personality, 34, 141-177.

Schmitt, D. P., \& Buss, D. M. (2001). Human mate poaching: Tactics and temptations for infiltrating existing mateships. Journal of Personality and Social Psychology, 80, 894-917.

Schmitt, D. P., Shackelford, T., Duntley, J., Tooke, W., \& Buss, D. M. (2001). The desire for sexual variety as a tool for understanding basic human mating strategies. Personal Relationships, 8, 425-455.

Simpson, J. A. (1990). Influences of attachment styles on romantic relationships. Journal of Personality and Social Psychology, 59, 971-980.

Simpson, J. A. (1999). Attachment theory in modern evolutionary perspective. In J. Cassidy \& P. R. Shaver (Eds.), Handbook of attachment (pp. 115-140). New York: Guilford.

Simpson, J. A., \& Gangestad, S. W. (1991). Individual differences in sociosexuality: Evidence for convergent and discriminant validity. Journal of Personality and Social Psychology, 60, 870-883.

Simpson, J. A., \& Rholes, W. S. (Eds.). (1998). Attachment theory and close relationships. New York: Guilford.

Smuts, B. B. (1985). Sex and friendship in baboons. New York: Aldine de Gruyter.

Spence, J. T., \& Helmreich, R. L. (1978). Masculinity and femininity: Their psychological dimensions, correlates, and antecedents. Austin: University of Texas Press.

Sroufe, L. A. (1983). Infant-caregiver attachment and patterns of adaptation in preschool: The roots of maladaptation and competence. In M. Perlmutter (Ed.), The Minnesota Symposia on Child Psychology: Vol. 16. Development and policy concerning children with special needs (pp. 41-83). Hillsdale, NJ: Erlbaum.

Stephan, C. W., Bachman, G. F. (1999). What's sex got to do with it? Attachment, love schemas, and sexuality. Personal Relationships, 6, 111-123.

Symons, D. (1979). The evolution of human sexuality. New York: Oxford University Press. 
Tamres, L. K., Janicki, D., \& Helgeson, V. S. (2002). Sex differences in coping behavior: A meta-analytic review and an examination of relative coping. Personality and Social Psychology Review, 6, 2-30.

Taylor, S. E., Klein, L. C., Lewis, B. P., Gruenewald, T. L., Gurung, R. A. R., \& Updegraff, J. A. (2000). Biobehavioral responses to stress in females: Tend-and-befriend, not fight-or-flight. Psychological Review, 107, 411-429.

Trivers, R. (1972). Parental investment and sexual selection. In B. Campbell (Ed.), Sexual selection and the descent of man: 1871-1971 (pp. 136-179). Chicago: Aldine.

United Nations Development Programme (2001). Human development report 2001. New York: Oxford University Press.

United Nations Statistics Division (2001). World population prospects: The 2000 revision, Volume 1: Comprehensive tables (United Nations publication, Sales No. E.01.XIII.8).

van de Vijver, F. J. R., \& Leung, K. (2000). Methodological issues in psychological research on culture. Journal of Cross-Cultural Psychology, 31, 33-51.
Van IJzendoorn, M. H., \& Sagi, A. (1999). Crosscultural patterns of attachment: Universal and contextual dimensions. In J. Cassidy \& P.R. Shaver (Eds.), Handbook of attachment (pp. 713-734). New York: Guilford.

Waters, E., Merrick, S., Treboux, D., Crowell, J., \& Alberstein, L. (2000). Attachment security in infancy and early adulthood: A twenty-year longitudinal study. Child Development, 71, 684-689.

Whitley, B. E. (1996). Principles of research in behavioral science. Mountain View, CA: Mayfield.

Williams, J. E., \& Best, D. L. (1990). Measuring sex stereotypes: A multination study (revised ed.). Newbury Park, CA: Sage.

Wood, W., Christensen, P. N., Hebl, M. R., \& Rothberger, H. (1997). Conformity to sex-typed norms, affect, and the self-concept. Journal of Personality and Social Psychology, 73, 523-535.

Wood, W., \& Eagly, A. H. (2002). A cross-cultural analysis of the behavior of men and women: Implications for the origins of sex differences. Psychological Bulletin, 128, 699-727. 